\title{
UNANI CONCEPT AND MANAGEMENT OF QAI (NAUSEA) \& GHASIYAN (VOMITING)-A REVIEW
}

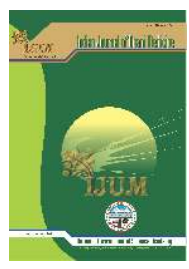

\author{
Musarrat $\mathrm{Ali}^{1}$, Shariq Shamsi ${ }^{2}$, Abuzar Lari $^{3}$ and Zaid Iqbal ${ }^{4}$ \\ ${ }^{1}$ Lecturer, Dept. of Ilmul Saidla, Mohammadia Tibbia college Malegaon \\ ${ }^{2}$ Lecturer Dept. of Ilmul saidla, NIUM, Bangalore \\ ${ }^{3}$ Lecturer Dept. of Ilaj Bit Tadbeer, Mohammadia Tibbia College, Malegaon, \\ ${ }^{4}$ Lecturer Dept. of Tashreeh ul badan, Mohammadia Tibbia College, Malegaon
}

\section{Review Paper}

Received: 15.08.2021

Revised: 22.08.2021

Accepted: 28.08.2021

\section{ABSTRACT}

According to Unani System of Medicine vomiting can be defined as the movement of stomach for elimination of gastric content through mouth. The matter of vomiting always found in gastric cavity (Jof-e-meda). Renowned unani physicians discussed about Qai and Ghasiyan in detailed, also explained the useful single drugs and compound formulations for treating nausea and vomiting. The only difference between nausea and vomiting is that, in vomiting the matter expel out through mouth, while in nausea it is not expelled. The matter of nausea is found in tissues of stomach and patient feels pain and tenderness in stomach. In this review paper we try to discussed unani concept and management of Nausea and vomiting.

No. of Pages: 3

No. of Tables: 1

References: 13

Keywords: Qai, Ghasiyan, Unani, Jof-e-meda

\section{INTRODUCTION}

Vomiting (Qai)As per the concept of Unani System of Medicine (USM), vomiting can be defined as the movement of stomach for elimination of gastric content through mouth. The matter of vomiting always found in gastric cavity (Jof-emeda). ${ }^{[1,2,3,4]}$

Retching (Tahu, Ubkai)Retching (Tahu or Ubkai) is a movement of stomach to eliminate the content of stomach but unable to eliminate it from mouth. The only difference between nausea and vomiting is, in vomiting the matter expel out through mouth while in nausea it is not. The matter of nausea is found in tissues of stomach and patient feels pain and tenderness in stomach ${ }^{[1,2,3,4,5]}$

Nausea (Ghasiyan or Matli) Ghasiyan or Matli is a condition in which stomach tries to expel out the unwanted matter which is adhere to it without any movement. ${ }^{[1,2,3]}$ ghasiyan or matli is a condition occurs before vomiting. It may reveal earlier or may persist for a long time, if the causative matter of ghasiyan founds in stomach then the disease persists for long time and if it falls from other organ then it reveals early. ghasiyan occurs due to accumulation of foul smelling excessive matter and liquid ${ }^{4}$. The matter of nausea is found in tissues of stomach and patient feels pain and tenderness in stomach. $^{[1,2,3,4,5]}$

\section{Causes (Asbab) of Nausea \& Vomiting}

Nausea and vomiting have similar causes, ${ }^{[1,2]}$ which is as follows: ulceration, irritation, tenesmus of stomach, improper dieting, collapse of stomach, renal colic, sever myalgia, hypersensitivity, hepatobiliary colic, uterine disease, cerebral trauma, abnormal humour, unwanted matter, spoiled Food, ${ }^{[6]}$ food poisoning, weakness of stomach, gastric disease like

*Corresponding author: ma714780@gmail.com 
inflammation of gastric mucosa, gastric ulcer, gastric carcinoma, atony of stomach, spasticity of stomach etc. Associated cause due to other disease cause activation of repulsive forces due to neurine stimulation, abdominal pain, cholilithiasis, inflammation of intestine, intestinal worms, cholecystitis, herniation, cardiac disorders, peritonitis, cirrhosis of liver, meningitis, brain tumor, coma, hysteria, ovarian disease, diabetes, Infective fevers like small pox, chicken pox, measles etc. Poisoning like alcohol, opium, chars, bhang, arsenic, tobacco, lead, mercuryetc. ${ }^{[4]}$

\section{Types of Nausea and Vomiting}

Nausea and vomiting of bile (Safrawi Qai wa Matli) In this type of vomiting the patient feels burning sensation and thrust, the vomitus contains bitter biliary Humour. ${ }^{[1,2]}$

Nausea and vomiting of phlegam(Bulgami Qai or Matli) In this type of vomiting and nausea is due to phlegmatic matter. [1]

Nausea and vomiting of black bile (Saudavi Qai wa matli) In this type the vomitus contains black bile. ${ }^{[1]}$

Aqueous and Acidic vomiting and nausea (Rutoobi and Humuzi Qai wa Matli) In aqueous and acidic vomiting, there is absence of burning and thrust but the patient feels flatulence and crackling sound in abdomen. The vomitus is bitter. $^{[4]}$

Vomiting due to crises (Bohran) In case of crises the vestigial or abnormal matter comes to the stomach which is expelled out through vomiting. ${ }^{[4]}$

Hematemesis (Qai-u-Dam) In hematemesis there is blood in vomitus due to trauma to vessels or abrasion, opening of ends of vessels or contusion to stomach. ${ }^{[4]}$

Vomiting due to infection (Ufooni Qai wa Matli) It occurs due to infectious matters which is accumulated in stomach ${ }^{1}$.

Vomiting due to worms (Qai e Didani)It is due to intestinal worms. $^{[1]}$

\section{Sign \& Symptoms of Nausea \& Vomiting}

\section{(Alamat e Qai-wa-Ghasiyan)}

- Phlegmatic symptoms with crackling sound and flatulence appear when the cause of vomiting and nausea is excessive liquid and acidity. Phlegmatic taste also feels by patient.

- Burning in abdomen and excessive thrust are the symptoms when the cause is bile. In this case taste of vomitus is bitter. Relevant symptoms appear accordingly when the cause is due to other disease.
- If vomiting occurs after one and half hours of food, it shows that the cause is in stomach and if it occurs after 23 hrs then may be the cause is in the small intestine and if after a long time, then the cause may be in large intestine.

- In gastric, biliary and intestinal disease, vomiting is accompanied with nausea, if applied light pressure on stomach the patient feels pain. ${ }^{[4]}$

\section{Diagnosis}

In cerebral disorder, vomiting occurs due to increase body temperature and slight stimulation may cause vomiting, if apply pressure on stomach patient not feels pain and tenderness. While it is opposite in gastric, intestinal and hepatic disorder ${ }^{[4]}$. The method of diagnosis of nausea and vomiting is that first rule out the involement of another disease like cholera, indigestion, abdominal pain, esophageal ulcer, ulceration in gums, gastritis, hepatitis, inflammation of spleen, inflammation of kidney, intestinal worms, febrile illness. If nausea and vomiting are present with any other disease, then it is called complication of that disease. If it is not due to any other disease, then check out its continuously, if it is persisting then it is itself as disease. In this case ask the diet of patient before occurring of vomiting and if patient has history of taking spoiled food then the cause of vomiting is indigestion. You should check for the alteration in the temperament plain with matter (Sue Mijaz sada maddi) if symptom present and stomach trying to expel out its content than it confirms that the disease is due to Sue mizaj sada maddi. If there is presence of symptom of humours then the cause behind it will be the humours ${ }^{[1]}$.

\section{Single drugs for Qai and Ghisyan (Nausea and Vomiting)}

\begin{tabular}{|c|c|}
\hline Mufrad Advia (Single Drug) & Botanical Name \\
\hline Sana & Casia angustifolia ${ }^{8}$ \\
\hline Atees Shireen & Aconitum betrophyllum ${ }^{8}$ \\
\hline Heel khurd & Elettaria cardamomam ${ }^{8}$ \\
\hline Anaar & Punica grantum ${ }^{9}$ \\
\hline Doob & Cynodon ductylan ${ }^{9}$ \\
\hline Nana & Mentha viridis ${ }^{10}$ \\
\hline Heel Kalan & Amomum Subulatum ${ }^{11}$ \\
\hline Aamla & Emblica officinalis $^{11}$ \\
\hline Papita & Carica papaya ${ }^{11}$ \\
\hline Khash & Andropogon muricatis ${ }^{11}$ \\
\hline Alocha & Prunus avium $^{11}$ \\
\hline bahi & Cydonia oblongata ${ }^{11}$ \\
\hline Peepal & Ficus religiosa $a^{11}$ \\
\hline
\end{tabular}




\begin{tabular}{|c|c|}
\hline Dhaniya & Coriander sativum ${ }^{11}$ \\
\hline Zarishk & Berperis vulgaris ${ }^{11}$ \\
\hline Tabasheer & Bambusa spinose ${ }^{11}$ \\
\hline Lemo & Citrus limon ${ }^{11}$ \\
\hline Narangi & Citrus limon $^{11}$ \\
\hline Post bairon-e-pista & Pistacia vera ${ }^{11}$ \\
\hline Lattku & Eriobotrya japonica $^{11}$ \\
\hline Podina & Mentha sylvestris ${ }^{11}$ \\
\hline Zaranbad & Curcuma zedoarea $^{11}$ \\
\hline
\end{tabular}

Compound drugs: Sharbat-e-Anaar, Sharbat-e-Hamaz, Sharbat-e-Hasram, Sharbat-e-Fataq, Sharbat-e-Khaskhas, Sharbat-e-Falsa, Sharbat-e-Ribas, Sharbat-e-Nilofar, Sharbat-e-Tamar Hindi, Sharbat-e-Limo, Sharbat-eSandal, ${ }^{[1,2]} J a w a r i s h-e-A n a r a i n$, Jawarish-e`Fawaqe, ${ }^{[1,2]}$ Jawarish-e-Tamar Hindi, ${ }^{[6]}$ Safoof Tabaseer, ${ }^{[1,2]}$ Qurs Mastagi, Qurs Papita, Qurs Rasan, Qurs Kunder, Qurs Samaq, ${ }^{[1,2]}$ Qurs Khabsul Hadeed, ${ }^{[6]}$ Laoq-e-Annar dana, ${ }^{[1,2]}$ Rub-e-Bahi, Rub-e-Saeb Sada, Rub-e-Ribas, Rub-eHamaz, ${ }^{[12]}$ Khameera-e-Uood tursh, Khameera-e-Sandal Tursh ${ }^{[1,2]}$ Sikan jabeen e Limoni, ${ }^{[6]}$, Habb-e-Zaranbad ${ }^{[13]}$

\section{CONCLUSION}

keeping the review in mind it can be concluded that unani system of medicine is a deep rooted system of medicine in India that deals with treatment of Nausea and vomiting since ancient times by adopting various mods of treatment Ilaj-biddawa (pharmacotherapy), Ilaj-bit-tadbeer (Regimental Therapy) and Ilaj-bil-ghiza (Diet therapy). A number of study carried out on different unani drugs like Zaranbad (Curcuma zadoria), Nana (Mentha viridis), Amla (Emblica officinalis) and Papita (Carica papaya) etc. and effective in treatment of Nausea and vomiting. However further research in this area is required to explore the secret behind these drugs in the treatment of Qai and Ghasiyan.

Acknowledgment: To NIUM Dept. of Saidla

Funding: Institutional funded

Conflict of interest:Nill

\section{REFERENCES}

1. Anonymous. The Unani pharmacopoeia of India. Part I. Volume $1^{\text {st }}$. New Delhi; Ministry of Health and Family
Welfare, Department of Ayurveda, Yoga \& Naturopathy, Unani, Siddha and Homoeopathy (Ayush), Government of India; 2009:11, 34-35,76.

2. Anonymous. The Unani pharmacopoeia of India. Part $1^{\text {st }}$, volume $4^{\text {th }}$. New Delhi; Ministry of Health and Family Welfare, Department of Ayurveda, Yoga \& Naturopathy, Unani, Siddha and Homoeopathy (Ayush), Government of India; 2009:11-12, 36-37.

3. Anonymous. The Unani pharmacopoeia of India. Part $1^{\text {st }}$, volume $5^{\text {th }}$. New Delhi; Ministry of Health and Family Welfare, Department of Ayurveda, Yoga \& Naturopathy, Unani, Siddha and Homoeopathy (Ayush), Government of India; 2009:54

4. Allama Hakeem Mohammad Kabeerudeen. Makhzan-ul-Mufradat (Kitab-ul-Advia). $2^{\text {nd }}$ edition. Delhi: Idara kitab-us-shifa; 2010.49-50,75-76,121,139$140,132,145,221-222,237,238,292,350,351,371$ 372,405-406.

5. Khan MA. Akseer-e-Azam. New Delhi: Idara Kitab-usshifa; 2011: 454-462

6. A. H. Md. Kabeerudeen. Al-Akseer. Volume $1^{\text {st }}$.Delhi: Ijaz publishing House Delhi;2003:752-765.

7. Hakeem Mohammad Ajmal Khan. Biyaz-e-Azmal. $1^{\text {st }}$ edition. Delhi: Ijaz publishing House Delhi; 2010:89-91.

8. Abul Mansoor-ul-Hasan Qamri. Minhaj-ul-Elaj.New Delhi; CCRUM, Ministry of AYUSH, Govt. of India New Delhi; 2008:191.

9. Anonymous. National formulary of Unani Medicine.Part-II.Vol.2. New Delhi: Ministry of Health and Family Welfare, Govt. of India; 2007: 28.

10. Hakeem Sayed Zillur Raheman. Kitab AlMurakkabat.Aligrh: Ibne sina Academy;2010:49

11. Anonymous. National formulary of Unani Medicine. part -III, $1^{\text {st }}$ edition, New Delhi: CCRUM, Ministry of Health and family welfare. Govt. of India; 2001:7,110,141,149.

12. Kabiruddin M. Alqarabadeen. $2^{\text {nd }}$ edition. New Delhi: CCRUM, Ministry of Health and family welfare. Govt. of India; 2006:97-98.

13. Anonymous. National formulary of Unani Medicine. part -1,1st edition, New Delhi: CCRUM, Ministry of Health and family welfare. Govt. of India; 2006:8,328329. 